\title{
Comprehensive Review of Olympic Movement Marketing
}

\author{
Hossein Eydi*, Hamed Farzi \\ Department of Physical Education and Sport Science, University of Razi \\ *Corresponding Author: eydihossein@gmail.com
}

Copyright (c) 2014 Horizon Research Publishing All rights reserved.

\begin{abstract}
Nowadays, Olympic Games have become one of the most large-scale and profitable global media events. In the world of sports, marketing, promotion and advertisement are fundamental tools for generating great profits. The current article will explore the issue of marketing-mediated sport events on the example of Olympic Games and will touch upon the issues of promotion of properly the Games, advertising athletes and participants, sources of profit for conducting the Games and new trends in marketing of Olympics. The issue will be discussed and is aimed at tracing the compliance of theoretical findings on advertisement, promotion and sponsorship strategies, on the example of one of the most profitable events, the Olympic Games. Thus, the work will focus on the issue of current developments of Olympic marketing and steps to be done in both theoretical and practical way to ensure further effectiveness and attractiveness of Olympic marketing program.
\end{abstract}

Keywords Marketing, Olympic Games, International Olympic Marketing

\section{Introduction}

Ever since the first Ancient Olympic Games in 776 BC the ultimate aim of competing, especially in athletics, was to be the best. Winning an Olympic event was the highest honor people could achieve [8]. What started as a competition to strengthen the bond between Greeks became an international affair in the 2 nd century AD, when competitors from outside Greece competed in the Olympic Games. In 393 AD the ancient Olympic Games were abolished because they were considered unchristian. After about 15 centuries the Greek government reinstated the Olympic Games as an international competition for the best amateur athletes. At the start of the modern Olympic Games in 1896, the Olympic Games were an elitist event, mostly for men [19]. Similar to the ancient Olympic Games, the Games were held every four years (a period called the Olympiad). The main purpose was to foster the ideal of "a sound mind in a sound body," and to promote friendship among nations. Initially, a second series of Games, the so-called intercalated Games, were supposed to be organized every four years in Athens in between the
Olympic Games. These series was not successful, but neither were the 1900 and the 1904 Olympic Games. To revitalize the Games Athens organized the first, and last, intercalated Games in 1906, which were successful.

Particularly huge profits are associated with marketing and advertising of Olympic Games. Nowadays, Olympic Games have become one of the most large-scale and profitable global media events. Though, the situation was not always like that. Starting as ancient Greek religious festival, where athletes competed in honor of Zeus and being revived in late nineteenth century as completely athletic games, Olympics ended up with becoming one of the most celebrated and profitable media events in the world. The current article will explore the issue of marketing-mediated sport events on the example of Olympic games and will touch upon the issues of promotion of properly the Games, advertising athletes and participants, sources of profit for conducting the Games, technologies used in Olympic marketing, new trends in marketing of Olympics and emerging threats to sports marketing. The issue will be discussed both in theoretical and practical network and is aimed at tracing the compliance of theoretical findings on advertisement, promotion and sponsorship strategies, with the practical implementation thereof on the example of one of the most profitable events in the sense of advertising, the Olympic Games. Thus, the work will focus on the issue of current developments of Olympic marketing and steps to be done in both theoretical and practical way to ensure further effectiveness and attractiveness of Olympic marketing programs. In this review article we try to describe marketing of Olympic movement and revenue generation of international Olympic committee (IOC).

\section{Methodology}

Research method has descriptive and type of review. Data was collected from book, article, IOC site and other resource.

\section{Result}

\subsection{Revenue Generation of IOC Marketing}


The Olympic marketing program has become the driving force behind the promotion, financial security and stability of the Olympic Movement. The Olympic Movement revenue generation program is designed to meet the following objectives:

- $\quad$ To ensure the independent financial stability of the Olympic Movement

- To create and maintain long-term marketing partnerships

- To ensure equitable revenue distribution throughout the entire Olympic Movement

- To ensure that the Olympic Games can be experienced by the maximum number of people throughout the world, principally via broadcast to TV and digital media platforms
- To protect the equity that is inherent in the Olympic image and ideal

The IOC generates revenue through six major programs. The IOC manages: 1 . Broadcast and new media rights 2 . The TOP worldwide sponsorship program 3. The IOC official supplier and licensing program. The Organizing Committees for the Olympic Games (OCOGs), under the direction of the IOC, manage: 4. Domestic sponsorship 5. Ticketing 6. Licensing programs within the host country. In addition, marketing programs are managed by the National Olympic Committees (NOCs) through their local sponsorship programs, and by the International Federations (IFs) through their own activities [6]. Also, figure 1, showed the income from Olympic marketing programs from 1980- 2004.

Table 1. Olympic Marketing Revenue (in millions of USD)

\begin{tabular}{|c|c|c|c|c|c|}
\hline & $1993-1996$ & $1997-2000$ & $2001-2004$ & $2005-2008$ & $2009-2012$ \\
\hline Broadcasting & 1.251 & 1.845 & 2.232 & 2.57 & 3.914 \\
\hline Top Program & 279 & 579 & 663 & 866 & 957 \\
\hline OGOC Domestic Sponsorship & 534 & 655 & 796 & 1.555 & 957 \\
\hline Ticketing & 451 & 625 & 411 & 274 & \\
\hline Licensing & 115 & 66 & 87 & 185 & \\
\hline Total & 2.63 & 3770 & 4189 & 5450 & \\
\hline
\end{tabular}

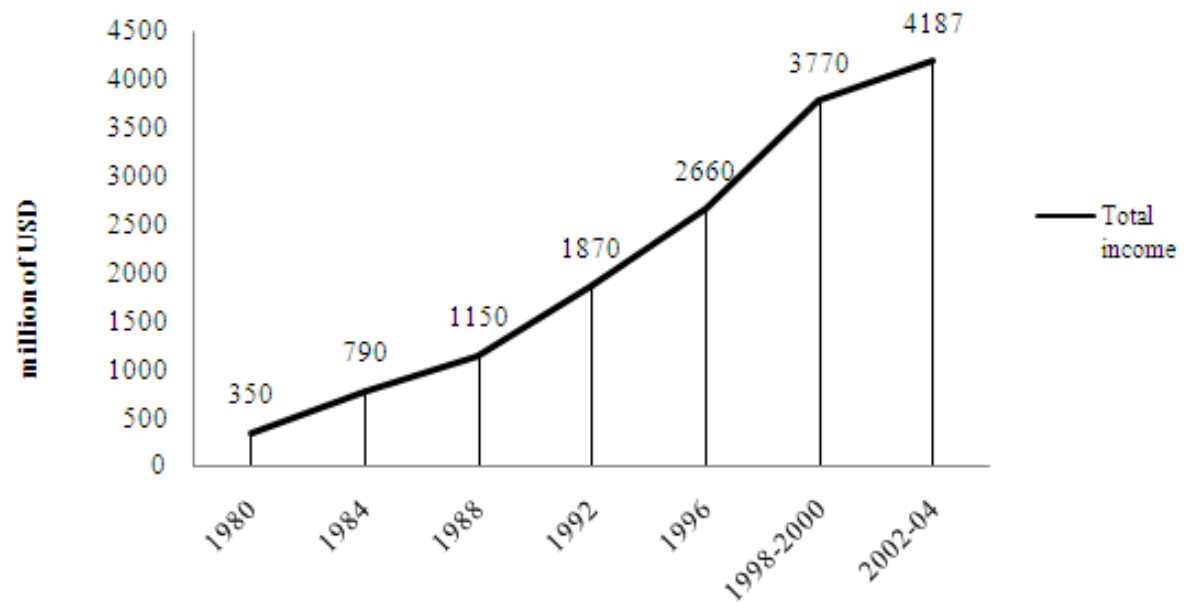

Figure 1. Evolution of income from Olympic marketing programs 1980- 2004 (in millions of USD) 


\subsubsection{Broadcast Partnerships}

The IOC is the owner of the global broadcast rights for the Olympic Games - including broadcasts on television, radio, mobile and internet platforms - and is responsible for allocating Olympic broadcast rights to media companies throughout the world through the negotiation of rights agreements. The fundamental IOC broadcast policy, as set forth in the Olympic Charter, is to ensure the widest possible audience for the Olympic Games. Olympic broadcast partnerships have been the greatest source of revenue for the Olympic Movement for more than three decades, and television coverage has been the single largest factor in the growth of the Olympic Games worldwide, ever since the London Olympic Games became the first to be broadcast into homes in 1948. The sale of television rights is the main source of revenues for the Olympic Movement and is the main medium for the promotion of the Olympic Games and Olympic ideals around the world. Olympic television coverage also enables viewers to see the events free of charge around the world, thanks to an agreement with the television channels. Although the relation between sport and television began with the advent of television itself, it was not until after the 1960s that televised sports became a mainstream interest of a sizable proportion of the world's population. Programmers were quick to realize that sports broadcasts increased audience ratings and the corresponding demand for advertising space [19]. They also realized that the cost of sports coverage was much lower than that of producing their own quiz shows and documentaries [11]. For sport, the arrival of television raised the value of its assets: publicity hoardings within the stadium were seen by an audience far beyond those physically present at the event, and their cost rose accordingly. This peculiar link led to what several commentators call the "TV Sport System", in which there were apparently no losers: the sports organizations earn more in advertising, sponsorship and television revenues, the television channels spend less to cover the events than they earn from the resulting advertising revenues; the advertising companies reach a wide and segmented audience justifying their advertising outlay [8]. In Munich'72 television represented 5.2\% of total income, in Montreal'76, 5.2\%, and in Moscow'80, 8.2\%. After Los Angeles'84 a change took place in the relation between television and the Olympics, and television revenues were neck and neck with sponsorship incomes. In more recent Games, television income has always been in excess of $25 \%$ and now tends to amount to around $50 \%$. Revenues from Olympic television rights have risen considerably.

Table 2. Evolution of revenues from Olympic television rights and countries receiving coverage (1972-2008)

\begin{tabular}{|c|c|c|c|}
\hline Year & Organizing cities & $\begin{array}{c}\text { Countries receiving } \\
\text { television coverage }\end{array}$ & $\begin{array}{c}\text { Revenues from } \\
\text { television rights (USD) }\end{array}$ \\
\hline 1972 & Sapporo- Munich & 98 & 26.3 \\
\hline 1976 & Innsbruck- Montreal & 124 & 43.6 \\
\hline 1980 & Lake Placid- Moscow & 111 & 122 \\
\hline 1984 & Sarajevo- Los Angeles & 156 & 390 \\
\hline 1988 & Calgary- Seoul & 160 & 728 \\
\hline 1992 & Albertville- Barcelona & 193 & 928 \\
\hline $1994-96$ & Lillehammer- Atlanta & 214 & 1251 \\
\hline $1998-2000$ & Nagano- Sydney & 220 & 1845 \\
\hline $2002-04$ & Salt Lake C.- Athens & 220 & 2236 \\
\hline $2006-08$ & Torino- Beijing & 220 & 2546.7 \\
\hline
\end{tabular}

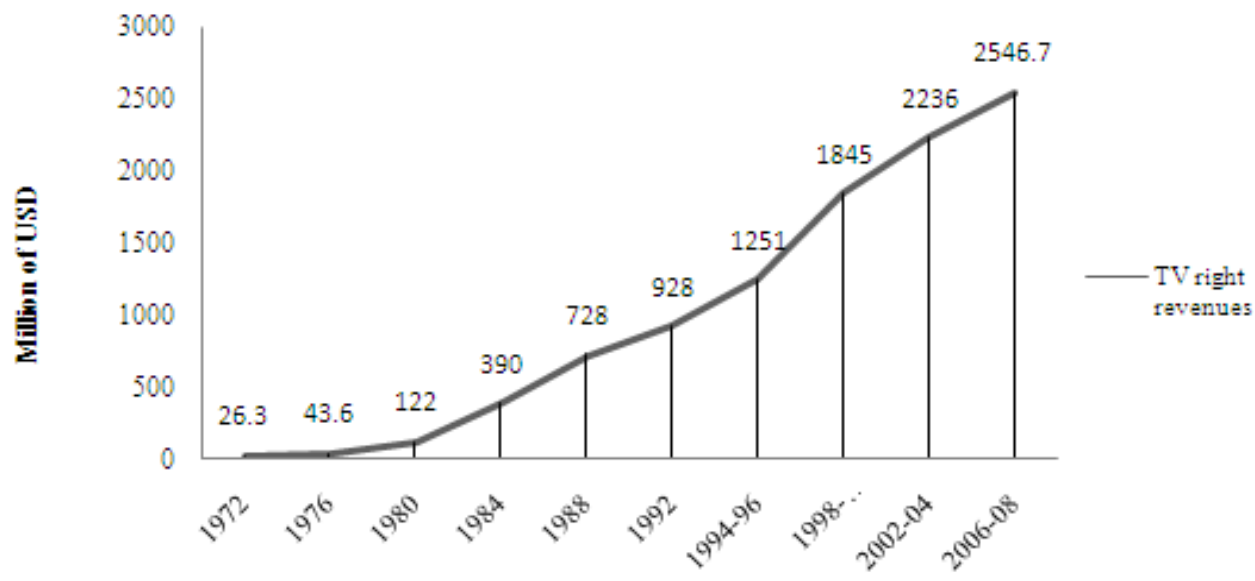

Figure 2. Evolution of revenues from Olympic television rights 1972-2008 (in millions of dollars) 


\subsubsection{TOP Sponsorship Program}

The Olympic Partnership (TOP) program is the worldwide sponsorship program managed by the IOC. Created in 1985, TOP provides each Worldwide Olympic Partner with exclusive global marketing rights to the Olympic Games within a designated product or service category, generating revenue and support to benefit the Olympic Movement. Sponsorship, both at international and local scale, is essential for the Olympic Movement and the Games. Business sector support involves more than financial contribution: Olympic sponsors provide technology, products, services, knowledge and personnel to contribute to smooth running of the Games. The Olympic Games have become one of the most attractive properties, bringing in significant amounts of revenues from broadcasting, sponsorship and licensing agreements. For the period 2001-2004 the International Olympic Committee (IOC) reported revenues that exceeded US $\$ 4,000$ million. Fully $34 \%$ of those revenues were the result of corporate sponsorship agreements of The Olympic Partner program (TOP), the IOC-managed crown jewel of Olympic sponsorship ("Marketing Revenue," n. d.). Local organizing committees of the Olympic Games (OCOGs) receive approximately $20 \%$ (Winter Games) to $30 \%$ (Summer Games) of the IOC's sponsorship revenues, but need to supplement that amount with revenues from their own sponsorship agreements. National sponsorships provide unique opportunities for local companies to develop an association with the Olympic brand and to receive marketing and other corporate benefits. By providing monetary and in-kind support to the organizing committee and by investing to exploit rights received through their sponsorship agreements national sponsors can become a fixture in a country's Olympic effort for at least four. The term Olympic sponsorship includes several different types of agreement between the Olympic Movement and business at different levels. However, the TOP program (The Olympic Partners) covers global sponsorship agreements between companies and the Olympic Movement as a whole. The program has four main objectives:

a) To ensure the stability of the Olympic Movement (for the purpose of promoting Olympism around the world) and to diversify income sources, which from the late 60 s to the 80 s came almost exclusively from North American television stations?

b) To create a structure permitting economic stability for Organizing Committees and avoiding the need to invent new systems for each Olympic Games;

c) To ensure that sponsorship revenues are distributed appropriately among members of the Olympic Movement; and

d) To avoid uncontrolled commercialization of the Olympic Movement, by reducing the number of associated companies and through control of the use of Olympic insignia (IOC, 1994b).

The origins of the TOP program go back to the period running up to Los Angeles Games'84. In 1983, the IOC asked the international marketing firm ISL to develop a global marketing program with benefit packets for potential members. This decision was taken in the light of approaches from a number of multinationals with regard to a worldwide association with the Olympic Movement [19].

Firstly, the TOP program simplified matters for the companies wishing to be associated with the Olympic Movement at global scale. Prior to 1988, a company wishing to be a global sponsor had to negotiate rights separately with the two Organizing Committees of each Olympiad, all the National Olympic Committees and the IOC. In fact, no company had ever achieved these rights and very few -Coca-Cola being one exception- achieved them for even a significant number of countries. The program meant that contacts were centralized in the IOC through ISL. In 2001, ISL went bankrupt and, nowadays, the global sponsor must negotiate a single contract with the IOC marketing department, which is the responsible of this area.

Secondly, the TOP contract is valid throughout the complete Olympiad. From the outset it included sponsorship rights for both the summer and Winter Games: the sponsors had a four-year period in which to exploit various marketing strategies. The internal dynamics of the TOP program led to programming of the winter and Summer Games in different years, as has occurred since Lillehammer' 94 .

Thirdly, in addition to the usual benefits for sponsors (i.e., publicity), the program also offered other commercial advantages, including ongoing marketing advice.

The first implementation of the TOP program covered the 1985-88 periods (Calgary' 88 and Seoul' 88 ). There were a total of nine participants, substantially fewer than the 20 originally anticipated. Each participant contributed a minimum of ten million dollars (IOC, 1992). This was the first international Olympic sponsorship program, if not yet truly global in scale, since only 150 of the 161 National Committees participated. Cuba, Libya, Venezuela and Greece were among those against the program since they saw it as contributing to excessive commercialization of the Games. The main beneficiaries of the program were the Seoul' 88 and Calgary' 88 Organizing Committees.

In TOP II (Barcelona'92 and Albertville'92), which ran between 1988 and 1992, a total of 12 companies participated. The initial price for each was USD $20 \mathrm{~m}$, although a number of companies negotiated a lower figure. 169 NOCs participated and benefited from the program, i.e., all the National Committees with the exception of Iraq, Afghanistan and Cuba. A total of $50 \%$ of the income generated went to the Local Organizing Committees and the remainder was divided between the participating NOCs and the IOC, which received $6.5 \%$. Ten companies signed up for TOP III, the first to achieve unanimous consensus from all 196 NOCs. Each company paid a total of USD 40m (twice the TOP II figure) in the form of cash, goods and services for the Lillehammer'94 and Atlanta'96 Games. The TOP companies operated all over the world, although the bulk of their capital was from the United States. In 1989, $80 \%$ of the Olympic Movement's financial support came 
from North American companies, both in terms of sponsors and television channels. At present, there is a trend towards geographical diversification and Japanese companies have increased their participation. The biggest contract was that signed by IBM in 1993 for approximately USD 200m, valid for a total of eight years and covering two Summer Games (Atlanta'96 and Sydney 2000) and two Winter Games (Lillehammer'94 and Nagano'98). A sizable proportion of the total payment was in kind: computer technology, including the results service for all four Games. A major advantage for IBM as a TOP III sponsor was the display of its logo on the top of the television screen every time a result appeared. Although IBM was a sponsor in 16 of the last 18 Games, it only had the right to display its logotype in the host countries, since it was not a TOP participant but a sponsor of the respective Organizing Committees [19]. After the Atlanta'96 Games, a number of the companies decided not to renew their contracts pointed to the sharp rise in prices (from ten million dollars in TOP I, to 20 million in TOP II and 40 million in TOP III). Several opted to channel their sponsorship resources into competitions allowing advertising in the stadiums, with the guarantee of screen time, such as the FIFA World Cup and the athletics World Championships, including such companies as Philips and M\&M Mars.

TOP IV covered the Nagano'98 Winter Games and the Sydney 2000 Summer Games. A total of 11 companies participated and together they paid a total of some USD $550 \mathrm{~m}$.

TOP V included the Salt Lake City 2002 Winter Games and the Athens 2004 Summer Games. The number of participants was reduced to ten: those missing from the TOP IV program were IBM and UPS. The only new member was Sema, now owned by Atos Origin, which took IBM's place.

Table 3. Global Olympic Sponsors (1985-2008)

\begin{tabular}{|c|c|c|c|c|c|}
\hline $\begin{array}{c}\text { TOP I } \\
\text { Calgary-Seoul } \\
1985-88\end{array}$ & $\begin{array}{c}\text { TOP II } \\
\text { Albertville- } \\
\text { Barcelona } \\
\text { Coca-Cola }\end{array}$ & $\begin{array}{c}\text { TOP III } \\
\text { Lillehammer- } \\
\text { Atlanta } \\
1989-96\end{array}$ & $\begin{array}{c}\text { TOP IV } \\
\text { Nagano-Sydney } \\
1997-2000\end{array}$ & $\begin{array}{c}\text { TOP V } \\
\text { Salt Lake City- } \\
\text { Athens } \\
2001-04\end{array}$ & $\begin{array}{c}\text { TOP VI } \\
\text { Torino- Beijing } \\
2005-2008\end{array}$ \\
\hline Kodak & Kodak & Coca-Cola & Coca-Cola & Coca-Cola & Coca-Cola \\
\hline $\begin{array}{c}\text { Time/Sports } \\
\text { Illustrated }\end{array}$ & $\begin{array}{c}\text { Time/Sports } \\
\text { Illustrated }\end{array}$ & $\begin{array}{c}\text { Time/Sports } \\
\text { Illustrated }\end{array}$ & $\begin{array}{c}\text { Time/Sports } \\
\text { Illustrated }\end{array}$ & $\begin{array}{c}\text { Time/Sports } \\
\text { Illustrated }\end{array}$ & Kodak \\
\hline VISA & VISA & VISA & VISA & VISA Origin & VISA \\
\hline Brother Industries & Brother Industries & Xerox & Xerox & Xerox & Manulife \\
\hline Phillips & Phillips & US. Postal Service & US. Postal Service & Samsung & Samsung \\
\hline $3 M$ & $3 M$ & IBM & IBM & Sema & GE \\
\hline Federal Express & US. Postal Service & John Hancock & John Hancock & John Hancock & Omega \\
\hline Panasonic & Panasonic & Panasonic & Panasonic & Panasonic & Panasonic \\
\hline & Bausch \&Lomb & Bausch \& Lomb & McDonald's & McDonald's & McDonald's \\
\hline & Ricoh & & Samsung & & Lenovo \\
\hline
\end{tabular}

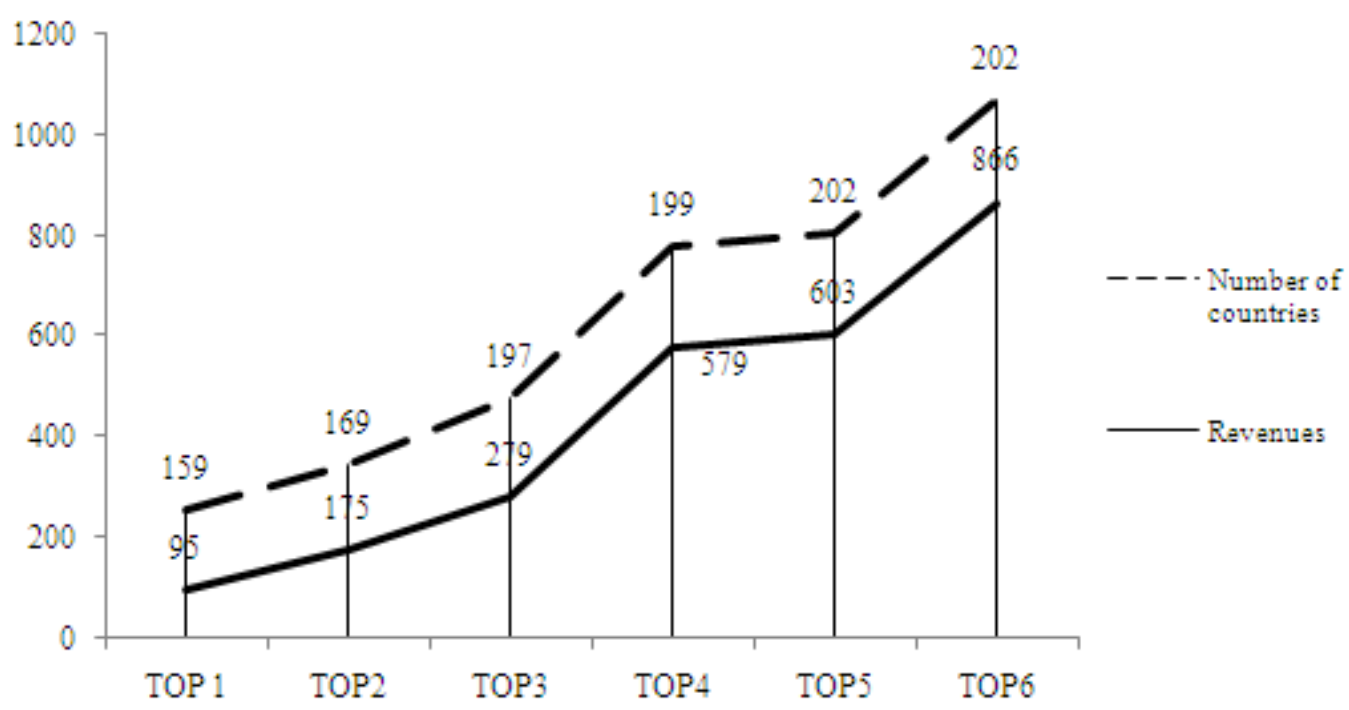

Figure 3. Evolution of TOP program (1985-2008) 
Further changes to the TOP VI sponsor line-up for the Torino 2006 and Beijing 2008 Games include the decision by Swatch to switch to its Omega brand, the involvement of GE (NBC's parent company), Lenovo, and Johnson and Johnson in February 2006. The estimated value of TOP VI is a record USD $886 \mathrm{~m}$.

\subsubsection{Licenses and other operations}

The official Olympic licensing program covers products of the Organizing Committees, National Olympic Committees and the IOC. These products bear the emblems and mascot of the Games or the National teams and are designed to commemorate the event. Olympic coins, stamps and pins are another feature of this area. Olympic licensing programs serve for creative and active promotion of the Olympic brand image. They also provide a showcase for the Games, serving to entice consumers and maintain a high standard of Olympic marketing thus improving its image and ensuring high-quality products for the public. The licensing program provides for manufacture of products with an official license from the Organizing Committees, the National Olympic Committees, and the International Olympic Committee. These products bear the Olympic or National Team emblems and mascots, and are designed to commemorate the event.

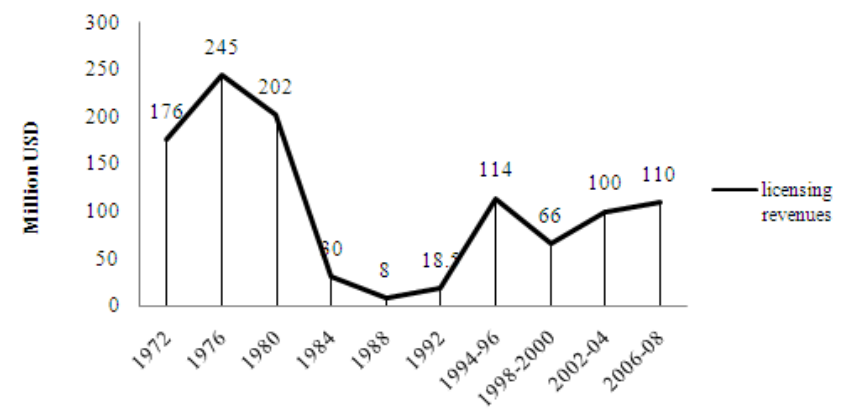

Figure 4. Evolution of Olympic Games licensing revenues (1980-2008)

The licensing program operates at three levels within the Olympic Movement:

\section{- The Organizing Committee}

OCOGs authorize companies to produce Olympic souvenirs. These companies generally pay a fee of between 10 and $15 \%$ for use of the emblems. The merchandise is usually of novelty or commemorative value and includes pins, t-shirts and caps.

\section{- National Olympic Committees}

NOCs authorize companies to produce specific souvenirs of their National Teams. These companies generally pay a percentage of between 10 and $15 \%$ for the use of the emblems. As for the OCOGs, the merchandise is usually of novelty or commemorative value including pins, $\mathrm{T}$-shirts and caps.

\section{- The International Olympic Committee}

The IOC operates a limited licensing program around the world in specific fields including films, videogames and other multimedia products. Over recent years, licensing revenues have never represented more than $2 \%$ of total income. Nevertheless, as table 5 shows, prior to the $1980 \mathrm{~s}$ these earnings tended to be higher due to the revenue from Olympic coins. At Moscow'80, a special effort was made in licensing and revenue represented $26.8 \%$ of the total.

\subsubsection{Ticketing}

Revenues from ticket sales for the sporting events and opening and closing ceremonies represent more than $10 \%$ of the Organizing Committee's income. The Internet boom has opened up new financial possibilities for the Olympic Movement and the establishment of a new paradigm of economic relations with the sponsors, broadcasters and the potential to reach new audiences. Ticket sales programs enable the public to buy tickets for the sporting events and the opening and closing ceremonies not only from within the host countries but from anywhere in the world. At present, revenues from ticket sales represent $10 \%$ of the total income of the Local Organizing Committee. The International Olympic Committee receives approximately 5\% of this total.

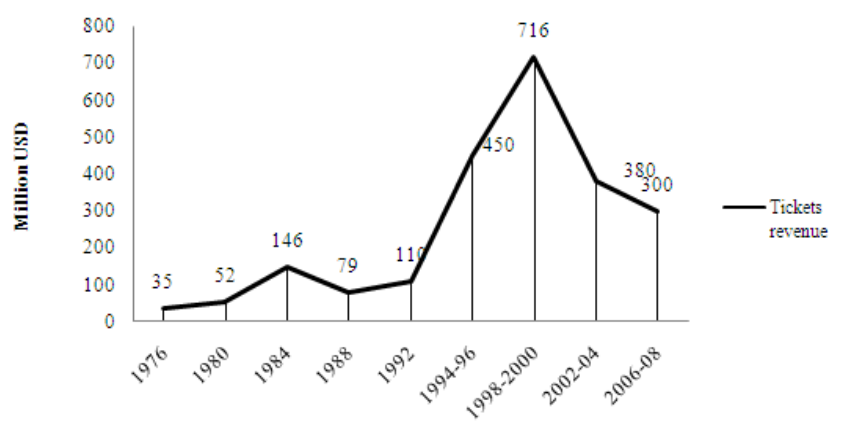

Figure 5. Evolution of Olympic Games ticket sale revenues 1976-2008 (in millions of dollars)

\subsection{Revenue Distribution}

The IOC redistributes $92 \%$ of marketing revenues among the Olympic Family (OCOGS, NOCs and International Sports Federations). The IOC retains $8 \%$ of the revenues to cover management, administration and operating costs (see Figure 6). The IOC distributes over $90 \%$ of Olympic marketing revenue to organizations throughout the Olympic Movement, in order to support the staging of the Olympic Games and to promote the worldwide development of sport. The IOC retains under $10 \%$ of Olympic marketing revenue for the operational and administrative costs of governing the Olympic Movement.

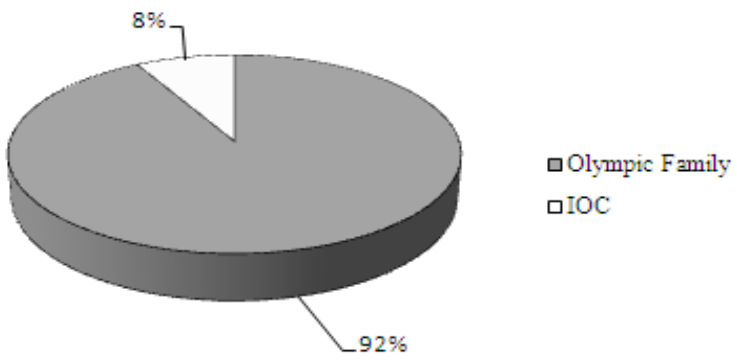

Figure 6. Olympic Marketing Revenue Distribution 


\subsubsection{Olympic Marketing contribution to the OCOGS}

The IOC provides a contribution from marketing revenues raised to the OCOGs to support the staging of the Olympic Games and Olympic Winter Games. In addition, beginning in Vancouver 2010, the IOC has entirely funded the host broadcaster operations, managed by Olympic Broadcast Services. The summer and winter OCOGs of each Olympic quadrennium generally share approximately $50 \%$ of TOP programme revenue and goods and services contributions. The IOC today contributes $49 \%$ of the Olympic broadcast revenue for each Game to the OCOG. (Prior to 2004, the IOC provided $60 \%$ of Olympic broadcast revenue to the OCOG.)

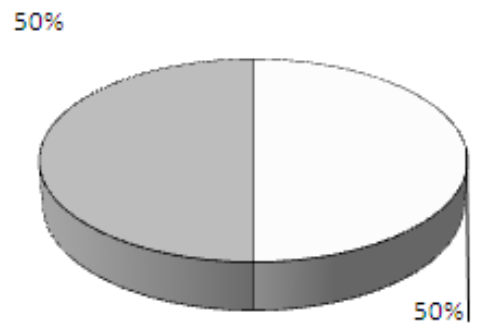

口summer and winter OCOGs

口Olympic Movement

Figure 7. TOP Program Revenue Distribution

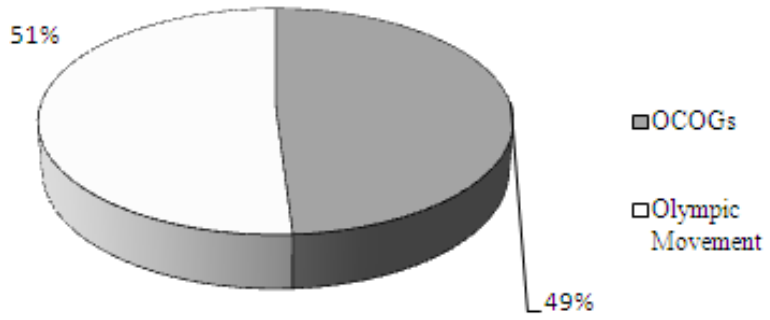

Figure 8. Broadcast Revenue Distribution

\subsubsection{Olympic Marketing contribution to the NOCs}

The NOCs receive financial support for the training and development of Olympic teams, Olympic athletes and Olympic hopefuls. The IOC distributes TOP program revenue to each of the 205 NOCs throughout the world. The IOC also contributes Olympic broadcast revenue to Olympic Solidarity - the body responsible for managing and administering the share of the television rights of the Olympic Gameshttp://www.olympic.org/olympic-solidarity -commission/ - that is allocated to the National Olympic Committees (NOCs). Olympic Solidarity assists the NOCs and the continental associations with their efforts to develop sport through programs carefully devised to match their specific needs and priorities. The continued success of the TOP program and Olympic broadcast agreements has enabled the IOC to provide increased support for the NOCs with each Olympic quadrennium. Substantial additional indirect financial support is provided to the NOCs through the provision of the athletes' village and travel grants for the Olympic Games.

Separate reporting is conducted with regard to TOP revenue contributions to the NOC of the United States (USOC) and of the host countries for each quadrennial. The figures presented above do not include the contributions to the USOC and the host country NOCs.

Table 4. Olympic Marketing Revenue Contributions to NOCs (Millions USD)

\begin{tabular}{|c|c|c|c|}
\hline & $\begin{array}{c}\text { Broadcast Revenue } \\
\text { via } \\
\text { Olympic Solidarity }\end{array}$ & $\begin{array}{c}\text { TOP } \\
\text { Program }\end{array}$ & $\begin{array}{c}\text { Total } \\
\text { Revenue } \\
\text { to NOCs }\end{array}$ \\
\hline $\begin{array}{c}\text { Albertville / } \\
\text { Barcelona } \\
1989-1992\end{array}$ & 51.6 & 35 & 86.6 \\
\hline $\begin{array}{c}\text { Lillehammer / } \\
\text { Atlanta } \\
1993-1996\end{array}$ & 80.9 & 57 & 137.9 \\
\hline $\begin{array}{c}\text { Nagano / Sydney } \\
1997-2000\end{array}$ & 118.7 & 93 & 211.7 \\
\hline $\begin{array}{c}\text { Salt Lake / Athens } \\
2001-2004\end{array}$ & 209.5 & 110 & 319.5 \\
\hline $\begin{array}{c}\text { Torino/Beijing } \\
2005-2008\end{array}$ & 233.6 & 139 & 372.6 \\
\hline Total & 2.63 & 3770 & 4189 \\
\hline
\end{tabular}

\subsubsection{Olympic Marketing Contributions to International} Federations

The IOC provides financial support from Olympic marketing to the $28 \mathrm{IFs}$ of Olympic summer sports and the seven IFs of Olympic winter sports. These financial contributions, drawn from Olympic broadcast revenue, are provided to the IFs to support the development of sport worldwide. The IOC distributes Olympic broadcast revenue to the IFs after the completion of the Olympic Games and the Olympic Winter Games, respectively. The rising value of Olympic broadcast partnerships has enabled the IOC to deliver substantially increased financial support to the Ifs with each successive Game. The Olympic marketing contribution to the summer IFs following the 2000 Olympic Games represented more than a fivefold increase over the contribution that followed the 1992 Olympic Games. The Olympic marketing contribution to the winter IFs following the 2002 Olympic Winter Games likewise represented more than a fivefold increase over the contribution that followed the 1992 Olympic Winter Games.

Table 5. Olympic Marketing Revenue Contributions to IFs

\begin{tabular}{|c|c|c|c|}
\hline Year & Organizing cities & $\begin{array}{c}\text { Kind of Ifs of } \\
\text { Olympic }\end{array}$ & $\begin{array}{c}\text { Revenue } \\
\text { contribution to } \\
\text { IFs }\end{array}$ \\
\hline 1992 & Barcelona & $\begin{array}{c}\text { Summer } \\
\text { Sports }\end{array}$ & 7.6 \\
\hline 1992 & Albertville & Winter Sports & 17 \\
\hline 1994 & Lillehammer & Winter Sports & 20.3 \\
\hline 1996 & Atlanta & $\begin{array}{c}\text { Summer } \\
\text { Sports }\end{array}$ & 86.6 \\
\hline 1998 & Nagano & Winter Sports & 49.4 \\
\hline 2000 & Sydney & $\begin{array}{c}\text { Summer } \\
\text { Sports }\end{array}$ & 190 \\
\hline 2002 & Salt Lake & Winter Sports & 92.4 \\
\hline 2004 & Athens & $\begin{array}{c}\text { Summer } \\
\text { Sports }\end{array}$ & 254 \\
\hline 2006 & Torino & Winter Sports & 126 \\
\hline
\end{tabular}




\section{Conclusion}

The evidence provided above clearly indicates that the Grand National sponsors of the 2004 Olympic Games differed on their intentions to support their sponsorship agreements with the deployment of resources and capabilities. This inevitably led the companies to derive significantly different return on their Olympic investments. The most active companies seem to have approached sponsorship as a resource with a potential to make it a source of sustainable competitive advantage, whereas, the less active ones seemed to have missed this unique opportunity. Modern forms of sponsorship in the Olympic Movement began in the 1960s, and between 1968 and 1980 the number of sponsoring organizations grew rapidly. The Los Angeles Games of 1984 were run on a purely commercial model and the decision was taken to limit the number of sponsors but require them pay more for exclusivity, earning the Los Angeles Organizing committee USD100m as opposed to the USD10m earned through sponsorship by previous OCOGs. The Internet boom has opened up new financial possibilities for the Olympic Movement and the establishment of a new paradigm of economic relations with the sponsors, broadcasters and the potential to reach new audiences. This realization of these possibilities came under threat when the dot.com bubble burst producing resulting in widespread uncertainty about future developments in relation to the Internet. The IOC has been extremely cautious in formulating an Internet rights policy in what is a more challenging environment in terms of copyright protection and the maintenance of exclusivity for potential rights holders. Every new edition of the Olympic Games demonstrates the growing importance of the Internet as a medium for the consumption of the Games, how the IOC manages its online strategy in coordination with its sponsorship and television broadcast strategies remains to be seen.

\section{REFERENCES}

[1] M, Carroggio. Patrocinio deportivo: Del patrocinio de los Juegos Olímpicos al deporte local. Barcelona: Editorial Ariel, 1996.

[2] International Olympic Committee. Marketing Olympique du CIO. Lausanne: IOC, 1992.

[3] International Olympic Committee. Olympic Marketing Fact File. Lausanne: IOC, 1994a.
[4] International Olympic Committee. Olympic Marketing Fact File, XVII Olympic Winter Games, Lillehammer. Lausanne: IOC, 1994b.

[5] International Olympic Committee. Marketing Fact File 2002. Lausanne: IOC, 2002.

[6] International Olympic Committee. Revenue generation and distribution: facts and figures, Lausanne: IOC, 2005a.

[7] International Olympic Committee. Marketing Fact File 2005. Lausanne: IOC, 2005b.

[8] H, Lämmer. Commercialism as a dominant factor in the American sports scene: sources, developments, 'perspectives", International Review for the Sociology of Sport, 1992.

[9] Moragas, M, D. Los Juegos de la comunicación, Madrid: Fundesco, 1992.

[10] M, Moragas, N, Ribenburgh, J, Larson. Television in the Olympics. London: John Libbey, 1995.

[11] B. Mullin, J. S, Hardy, W, Sutton. A. Sport marketing. Illinois: Human Kinetics, 1993.

[12] OCOG 1912. The Official report of the Olympic Games of Stockholm 1912, the fifth Olympiad. Stockholm: Wahlström \& Widstrand, 1913.

[13] OCOG 1928. IXe Olympiade : rapport officiel des jeux de la IXe Olympiade, Amsterdam 1928. Amsterdam: J.H. De Bussy, 1931.

[14] OCOG 1932. The Games of the Xth Olympiad Los Angeles 1932: official report. Los Angeles: Xth Olympiade Committee of the Games of Los Angeles, 1933.

[15] OCOG 1952. The Official report of the Organizing Committee for the Games of the XV Olympiad Helsinki 1952. Porvoo: W. Söderström, 1955.

[16] OCOG 1956. The Official report of the Organizing Committee of the Olympiad Melbourne 1956. Melbourne: Organizing Committee of the XVI Olympiad, 1958.

[17] OCOG 1960. The Games of the XVII Olympiad Rome 1960: the official report of the Organizing Committee. Roma: Organizing Committee of the Games of the XVII Olympiad, 1960 .

[18] OCOG 1964 (). The Games of the XVIII olympiad, Tokyo 1964: the official report of the Organizing Committee. Tokyo: The Organizing Committee for the Games of the XVIII, Olympiad, 1966.

[19] M, J. Puig. Olympic marketing: historical overview, University lectures on the Olympics, 2006. 